レーザー解説

\author{
光ファイバーへのレーザー光結合 \\ 河 野 健 治* \\ (1994年1月31日 受理) \\ Coupling of Laser Light to Optical Fibers
}

Kenji KAWANO*

(Received January 31, 1994)

\begin{abstract}
This paper desribes a proceudure for calculating the coupling efficiencybetween two Gaussian beams with an emphasis on laser-diode light to single-mode fiber coupling. First, the concept of ray matrices is discussed and the ray matrices for lenses are derived. Second, spotsizesand the beam waist positions of transformed beams are calculated. Third,coupling efficiencies between two Gaussian beams are obtained in a general form. Finally, coupling characteristics are disscussed for various lens systems.
\end{abstract}

Key Words: Gaussian beam, Ray matrix, Laser beam, Single-mode fiber, Coupling efficiency

1.はじめに

半導体レーザーモジュールなどの個別デバイ スのみならず光導波路を用いた集積デバイスの 開発において, 光源と(光ファイバーを含めた) 光導波路，あるいは光導波路同士などの結合は 不可避であり, 光結合系の知識はデバイス開発 の上で基本となる。また, 定盤上での結合実験 を研究·開発の手段としている人々にとっても, 実験を効率よく進める上で光結合系の知識は有 用である。

本稿では, 光導波路として単一モード光ファ イバーを例にとり，ガウシアンビームと光線行 列を用いた光結合系の設計手法について述べ る。なお, 紙面に限りがあるため式の詳しい導
出を示すことは困難である。式の導出の過程は 文献(1)に詳述しているので必要であれば参照 していただきたい。

\section{2. ガウシアンビーム}

自然光や発光ダイオードなどの光源はランダ ムな位相を有するため互いに干渉し合わない光 (インコヒーレント光)を出射する発光点の集合 である。一方, レーザー光は位相が揃った可干 渉性のある光(コヒーレント光)を出射する。 レーザーや単一モード光ファイバーの基本モー ドはガウス形状で近似できるため，ガウシアン ビームによる光の取り扱いは有用である。以 下，ガウシアンビームの導出を行うとともに, 伝搬の様子を考察する。

*NTT光エレクトロニクス研究所集積光エレクトロニクス研究部 (テ243-01 厚木市森の里若宮3-1)

*Integrated Opto-electronics Laboratory, NTT Opto-electronics Laboratories, (3-1, Morinosato Wakamiya, AtsugiShi, Kanagawa Pref. 243-01) 
電荷がない媒質中におけるマクスウェル方程 式から導かれる電界Eに対するヘルムホルッ方 程式は次式で与えられる。

$$
\nabla^{2} \boldsymbol{E}+k^{2} \boldsymbol{E}=0
$$

ここで, $k$ は波数であり, $k^{2}=\omega^{2} \varepsilon \mu$ と表せる。

ここで, 我々が考察を進めているガウシアン ビームは，わずかに曲率を有しているものの光 軸 $(z$ 軸) 付近ではほぼ平面波に近い波面を持っ ていると仮定する。電界 $\boldsymbol{E}$ をスカ量である $E$ で置き換え,さらに

$$
E(x, y, z)=\psi(x, y, z) \exp (-\mathrm{j} k z)
$$

の形と置く。式(2)を式(1)に代入し, 平面波か らのずれを表す振幅 $\psi$ は伝搬軸方向にゆるやか に変化している $\left(\partial^{2} \psi / \partial z^{2}=0\right)$ とすると, 振幅 $\psi$ に対するフレネル方程式

$$
\frac{\partial^{2} \psi}{\partial z^{2}}+\frac{\partial^{2} \psi}{\partial y^{2}}-2 \mathrm{j} k \frac{\partial \psi}{\partial z}=0
$$

を得る。ここで, 式(3)の解 $\psi$ に次式を仮定する。

$\psi(x, y, z)=A \exp \left[-\mathrm{j}\left\{p(z)+\frac{k}{2 q(z)}\left(x^{2}+y^{2}\right)\right\}\right]$

なお, $A$ は任意定数, $p(z)$ と $q(z)$ は複素ビーム パラメータである。式(4)を式(3)に代入するこ とにより求めた $\psi$ より $E$ は次式で表される。

$$
\begin{gathered}
E(x, y, z)=\sqrt{\frac{2}{\pi}} \frac{1}{w(x)} \exp \{-\mathrm{j}(k z-\phi \\
\left.-\left(\frac{1}{w^{2}(z)}+\mathrm{j} \frac{k}{2 R(z)}\right) r^{2}\right\}
\end{gathered}
$$

ここで，パワーで規格化した。また，位置 $z$ に おけるスポットサイズ $w(z)$, 波面の曲率半径 $R$, および位相 $\phi$ は次式となる。

$$
\begin{aligned}
& w(z)=w_{0} \sqrt{1+\left(\frac{\lambda z}{\pi w_{0}^{2}}\right)^{2}} \\
& R(z)=z\left\{1+\left(\frac{\pi w_{0}^{2}}{\lambda z}\right)^{2}\right\}
\end{aligned}
$$

$$
\phi(z)=\tan ^{-1}\left(\frac{\lambda z}{\pi w_{0}^{2}}\right)
$$

式(5)のEは伝搬軸に回転対称な分布を有し, $r か ゙$ 無限大に扔いてのみ零に漸近し, 零点を持 たない。従って，これを0次のガウシアンビー ムと呼ぶ。

次に, ガウシアンビームの物理的な意味につ いて考察をしょう。式(5)からわかるように, $r\left(=\sqrt{x^{2}+y^{2}}\right)=w(z)$ とおくと, 電界 $E$ の振幅は

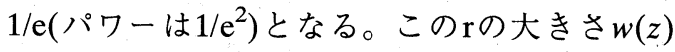
をガウシアンビームのスポットサイズと呼ぶ。

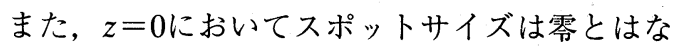
らずにある大きさ $w_{0}$ を持つ。ガウシアンビー ムの $z=0 に お け る$ 部分をビームウェストと呼 ぶ。 $\sqrt{x^{2}+y^{2}}<<z$ と $z$ が充分大きい領域では, 式(6), 式(7)は

$$
\begin{aligned}
& w(z) \doteqdot \frac{\lambda z}{\pi w_{0}} \\
& R(z) \doteqdot z
\end{aligned}
$$

となる。式(10)から，ガウシアンビームは球面 波のように振舞うことがわかる。Fig. 1にこの 0次のガウシアンビームの $\mathrm{z}$ 軸上での断面図を示 す。式(9), 式(10)から, 0次のガウシアンビー 厶の広がり角 $\theta$ は $w / R$, つまり

$$
\begin{aligned}
\theta & =\tan ^{-1}\left(\frac{\lambda}{\pi w_{0}}\right) \\
\doteqdot \frac{\lambda}{\pi w_{0}} & \text { 〔ラジアン }]
\end{aligned}
$$

と求められる。この式からわかるように, ビー ムウエストに拈けるスポットサイズが小さい

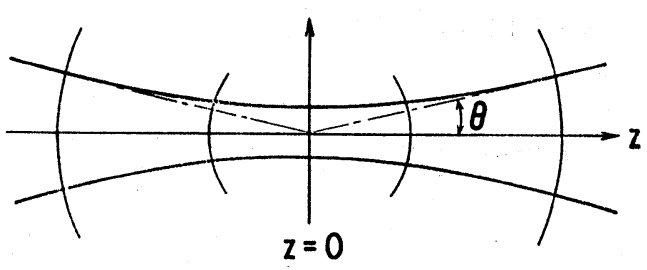

Fig. 1 Propagation of a Gaussian beam. 
と, 広がり角 $\theta$ は大きくなる。ちなみに, 1.55 $\mu \mathrm{m}$ で発振している半導体レーザーのスポット サイズを $1 \mu \mathrm{m}$ 程度とすると, ビームの広がり 角 $\theta$ は(半幅で)26度にもなる。

\section{3. 光線行列と像変換}

3. 1 レンズ系構成要素の光線行列

ここでは, 光線行列の 2,3 の基本要素を説明 する。なお, 光軸上の位置 $z$ における光線の光 軸からの距離を $r$, 傾きを $r^{\prime}(=\mathrm{d} r / \mathrm{d} z)$ とする。 また，光学系に入射する直前の $r$ と $r^{\prime}$ t $r_{1}, r_{1}^{\prime}$, 出射直後では $r_{2}, r_{2}^{\prime}$ とする。

(a) 厚み $d$ の平板

Fig. 2から直ちに

$$
\left(\begin{array}{l}
r_{2} \\
r_{2}^{\prime}
\end{array}\right)=\left(\begin{array}{ll}
1 & d \\
0 & 1
\end{array}\right)\left(\begin{array}{l}
r_{1} \\
r_{1}^{\prime}
\end{array}\right)
$$

の行列表現を得る。ここで示した2行2列の行列 を光線行列と呼ぶ。この式からわかるように， 光線行列を入射光の位置 $r_{1}$ と入射角 $r_{1}$ に作用さ せれば, その光線の出射位置 $r_{2}$ と, 出射角 $r_{2}{ }^{\prime}$ が 求まる。

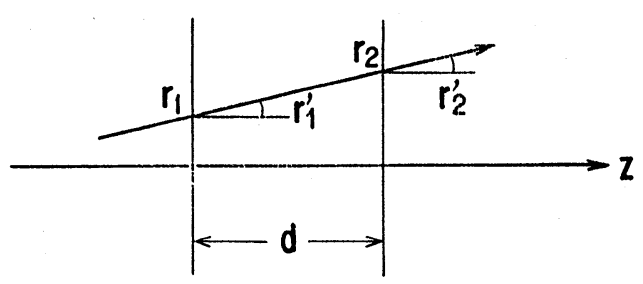

Fig. 2 A plate.

(b) 球状誘電体界面

Fig. 3に示すような界面形状が球面である球 状誘電体界面の光線行列は

$$
\left(\begin{array}{c}
r_{2} \\
r_{2}^{\prime}
\end{array}\right)=\left(\begin{array}{ccc}
1 & 0 \\
\frac{n_{2}-n_{1}}{n_{2}} & \frac{1}{R} & \frac{n_{1}}{n_{2}}
\end{array}\right)\left(\begin{array}{c}
r_{1} \\
r_{1}^{\prime}
\end{array}\right)
$$

で与えられる。ここで，この図のように入射光

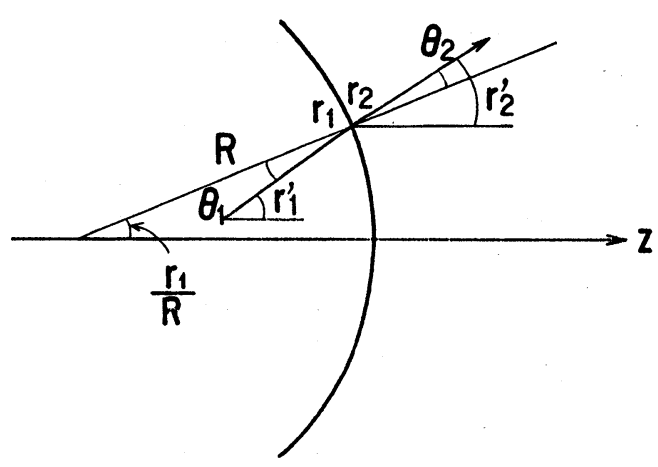

Fig. 3 A sphereical dielectric interface.

線に対して，曲面が凹であればその曲率半径 $R$ は正であり，逆に凸であればRは負とする。

(c) 薄肉レンズ

Fig. 4に示す焦点距離fの薄肉レンズでは，レ ンズの中心を通り屈折されない光線とレンズの 周辺部を通過し屈折される光線を考えると, 薄 肉レンズの光線行列として, 次式を得る。

$$
\left(\begin{array}{l}
r_{2} \\
r_{2}^{\prime}
\end{array}\right)=\left(\begin{array}{cc}
1 & 0 \\
-\frac{1}{f} & 1
\end{array}\right)\left(\begin{array}{l}
r_{1} \\
r_{1}^{\prime}
\end{array}\right)
$$

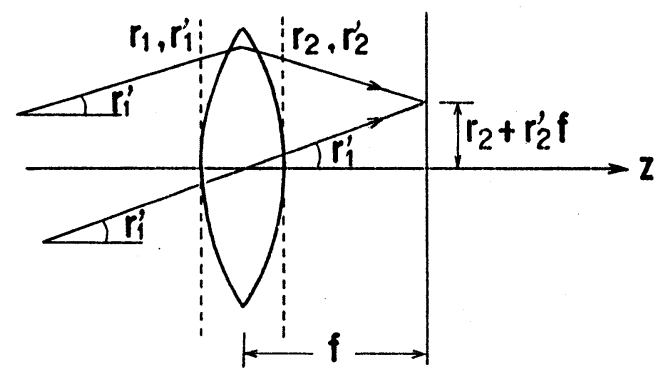

Fig. 4 A thin lens.

また, 光線行列で表される光学系構成要素は この他に, 屈折率が2乗変化する GRIN媒質, 球面ミラーなどがある。

一般に, 光線行列の行列要素は次のように $A, B, C, D$ で表すと便利である。

$$
\left(\begin{array}{l}
r_{2} \\
r_{2}{ }^{\prime}
\end{array}\right)=\left(\begin{array}{ll}
A & B \\
C & D
\end{array}\right)\left(\begin{array}{l}
r_{1} \\
r_{1}^{\prime}
\end{array}\right)
$$




\section{2 レンズの光線行列}

ここでは，球レンズなど実際のレンズを例に とり,レンズとしての光線行列を導くとともに， 焦点距離や主面など光学系設計に必要なパラ
メータを算出する方法について説明する。

(a) 球レンズ

Fig. 5に示すように，球レンズに光が左から 入射する場合の光線行列 $(M)$ は

$$
\begin{aligned}
& (M)=\overbrace{\left(\begin{array}{ccc}
1 & 0 \\
\frac{n_{1}-n_{2}}{n_{1}} & \frac{1}{R} & \frac{n_{2}}{n_{1}}
\end{array}\right)}^{\text {出射側球面 }} \overbrace{\left(\begin{array}{cc}
1 & 2 R \\
0 & 1
\end{array}\right)}^{\text {厚み } 2 R \text { の平板 }} \overbrace{\left(\begin{array}{ccc}
1 & 0 \\
\frac{n_{2}-n_{1}}{n_{2}} & \frac{-1}{R} & \frac{n_{1}}{n_{2}}
\end{array}\right)}^{\text {入射側球面 }} \\
& =\left(\begin{array}{cc}
\frac{2 n_{1}}{n_{2}}-1 & \frac{2 R n_{1}}{n_{2}} \\
-\frac{2\left(n_{2}-n_{1}\right)}{n_{2} R} & \frac{2 n_{1}}{n_{2}}-1
\end{array}\right)
\end{aligned}
$$

と示される。

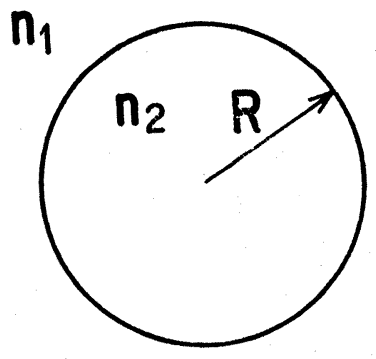

Fig. 5 A spherical lens.

レンズの最も重要なパラメータである焦点距 離 $f$ は光線行列の行列要素から, $f=-1 / C$ と表 される。焦点距離と並んで重要な概念としてレ ンズの主面があり, さらにこの主面には入射側 主面と出射側主面の 2 種類がある。入射側では 入射光にとってあたかも主面の位置に薄肉レン ズが存在するように見え, 出射側ではあたかも 出射側主面の位置に存在する薄肉レンズから光 が出射されているかのように見える。レンズの

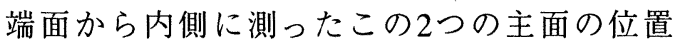
$h_{1}$ および $h_{2}$ は, $h_{1}=(D-1) / C, h_{2}=(A-1) / C$ と して求められる。

実際に球レンズについて, $f, h_{1}, h_{2}$ を求めて
みると，

$$
\begin{aligned}
& f=\frac{n_{2} R}{2\left(n_{2}-n_{1}\right)} \\
& h_{1}=h_{2}=R
\end{aligned}
$$

となり, 球レンズはその中心に置いた焦点距離 fの薄肉レンズで代表できることになる。また, 球の半径 $R$ と焦点距離 $f$ 比をレンズの開口数 $(N A)$ と呼ぶ。

(b) GRINロッドレンズ

球レンズの場合と同様な手順により, GRIN ロッドレンズの光線行列は

$$
(M)=\left(\begin{array}{cc}
\cos \left(\sqrt{A_{0}} d\right) & \frac{n_{1}}{n_{0} \sqrt{A_{0}}} \sin \left(\sqrt{A_{0}} d\right) \\
-\frac{n_{0} \sqrt{A_{0}}}{n_{1}} \sin \left(\sqrt{A_{0}} d\right) & \cos \left(\sqrt{A_{0}} d\right)
\end{array}\right)
$$

と求まる。ここで, 軸上屈折率を $n_{0}$, 収束パラ メータを $A_{0}$, ピッチ長を $p$ とした。焦点距離 $f お$ よび端面と主面間の距離 $h_{1}, h_{2}$ は

$$
h_{1}=h_{2}=\frac{n_{1}}{n_{0} \sqrt{A_{0}}} \tan (\pi p)
$$

と求まる。例えば, $n_{0}=1.59, \sqrt{A_{0}}=0.326 / \mathrm{mm}$ 
media 1

media 2

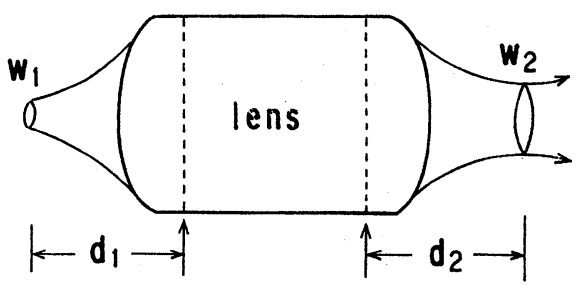

Fig. 6 Concept of beam transformation.

とすると, 0.25 ピッチでは

$$
f=h_{1}=h_{2}=1.93 \mathrm{~mm}
$$

となり,レンズの両端面に焦点がくる。従って, 平行光が入射した場合には, レンズの端面に結 像することになる。

以上の手順を用いれば，この他に先球GRIN ロッドレンズ，平凸レンズなど種々のレンズの 光線行列を求めることができる。

\section{3 像変換の公式}

ここでは，レーザー光を光ファイバーに結合 させるための光結合系の設計において, 最も重 要なスポットサイズと結像点の位置の算出法に ついて述べる。

Fig.6に像変換系の概念図を示す。ここで既 知の量は媒質 1 におけるスポットサイズ $w_{1}$ およ びビームウェストとレンズの入射側の主面間の 距離 $d_{1}$, また求めるべきのものは媒質 2 に出射 されたガウシアンビームのスポットサイズ $w_{2}$ およびビームウェストとレンズの出射側主面間 の距離 $d_{2}$ である。

レンズ系に入射する前と出射後の複素ビーム パラメータ $q_{1}$ と $q_{2}$ は次の式で表される。

$\frac{1}{q_{i}}=\frac{1}{R_{i}}-\mathrm{j} \frac{\lambda_{\mathrm{i}}}{\pi w_{i}^{2}}(i=1,2)$

これらの複素ビームパラメータ間には

$$
q_{2}=\frac{A q_{1}+B}{C q_{1}+D}
$$

の関係がある。ここで注意すべきことは式(22) の中の行列要素にはFig.6中の $d_{1}, d_{2}$ も誘電体平 板として含まれている点である。

媒質 $1 ， 2$ におけるビームウェストでは波面の 曲率半径 $R_{1}, R_{2}$ が無限大となるので, 複素ビー ムパラメー夕 $q_{1}, q_{2}$ は純虚数となる。

$$
q_{i}=\mathrm{j} \frac{\pi w_{i}^{2}}{\lambda i}(i=1,2)
$$

純虚数 $q_{1}$ を式(22)の $q_{2}$ に代入した結果を純虚

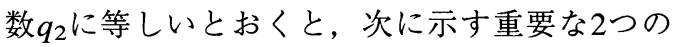
公式を得る。

$$
\begin{aligned}
& A C+\left(\frac{\lambda_{1}}{\pi w_{1}^{2}}\right)^{2} B D=0 \\
& \left(\frac{w_{2}}{w_{1}}\right)^{2}=\frac{\frac{\lambda_{2}}{\lambda_{1}}}{\left(\frac{\pi w_{1}^{2}}{\lambda_{1}}\right)^{2} C^{2}+D^{2}}
\end{aligned}
$$

ここで，一般に成立すな"口反定理 $A B-C D=1$ を用いた。

式(24)と式(25)の用い方は以下の通りであ る。すなわち, レンズ系の構成が決まると, 入 射側主面の位置 $h_{1}$, 従って $d_{1}$ がわかる。また, 入射ガウシアンビームのスポットサイズ $w_{1}$ も 与えられているので, 式(24)と式(25)より出射 ガウシアンビームのスポットサイズ $w_{2}$ と位置 $d_{2}$ が求まる。一方， $h_{2}$ より出射側の主面と端面 間の距離もわかっているので, 最終的にレンズ の端面とビームウェスト間の距離も算出できる ことになる。 $w_{2} / w_{1}$ を像倍率とよび $m$ で表すこ とにする。

なお，式(22)の代わりにそれを変形した

$$
\frac{1}{q_{2}}=\frac{C+\frac{D}{q_{1}}}{A+\frac{B}{q_{1}}}
$$

から出発すると, ビームウェストの位置 $d_{2}$ につ いては式(24)と同じ式を，またスポットサイズ $w_{2}$ については式(25)の代わりに 


$$
\left(\frac{w_{2}}{w_{1}}\right)^{2}=\frac{A^{2}+\left(\frac{\lambda_{1}}{\pi w_{1}^{2}}\right)^{2} B^{2}}{\frac{\lambda_{2}}{\lambda_{1}}}
$$

を得る。式(25)と式(27)は見かけ上形は異なっ ているものの, 同じ式に帰着できるので使用上 便利な方を用いればよい。

\section{4. ガウシアンビームの結合}

\section{1 結合効率}

まず，一般論で議論を進める。 $x$ 方向に $m$ 次, $y$ 方向に $n$ 次のガウシアンビームは

$$
\mathrm{TEM}_{m n}=f_{m}(x) g_{n}(y)
$$

で与えられる。ここで,

$$
\begin{aligned}
f_{m}(x)= & \left(\sqrt{\frac{2}{\pi}} \frac{1}{w(z) 2^{m} m !}\right)^{\frac{1}{2}} H_{m}\left(\frac{x}{w(z)} \sqrt{2}\right) . \\
& \exp \left(-\frac{x^{2}}{w^{2}(z)}-\mathrm{j} k \frac{x^{2}}{2 R(z)}\right)
\end{aligned}
$$

ただし，後の議論に影響を与えないので， $z$ 軸 方向の位相項は省略した。また， $g_{n}$ は式(29)に おいて， $m$ と $x$ を各々 $n$ と $y$ とで置き換えたもの となる。

さて, 入射モードが $x$ 方向には $m_{1}$ 次, $y$ 方向 には $n_{1}$ 次であるとすると，

$$
\text { 入射界 }=\phi_{m 1}(x) \phi_{n 1}(y)
$$

が成り立つ。この入射界が光ファイバーなどの 受光系に入射すると, 入射界は次式のように受 光系の固有モードで展開できる。

$$
\overbrace{\phi_{m_{1}}(x) \phi_{n_{1}}(y)}^{\text {入射界 }} \overbrace{\sum_{m_{2}=0} \sum_{n_{2}=0} C_{\substack{m_{1} n_{1} m_{2} n_{2} \\ \text { 入射系 受光系 }}}^{\text {結係数 }}(x) \psi_{n_{2}}(y)}^{\text {受光系の固有関数 }}
$$

ここで, 添え字は入射系については1, 受光系 については2としている。 $C_{m_{1} n_{1} m_{2} n_{2}}$ はx 方向とy
方向のモード番号が $\left(m_{1}, n_{1}\right)$ であるガウシアン ビームを受光系の固有関数で展開した際に受光 系の $\left(m_{2}, n_{2}\right)$ モードに付随する展開係数であり, $\left(m_{1}, n_{1}\right)$ モードから $\left(m_{2}, n_{2}\right)$ モードへの結合効率 は，以下のようにその絶対值の2乗で表される。

$$
\begin{aligned}
\left|C_{m_{1} n_{1} m_{2} n_{1}}\right|^{2} & =C_{m_{1} n_{1} m_{2} n_{2}} \cdot C_{m_{1} n_{1} m_{2} n_{2}}^{*} \\
& =\left|c_{m_{1} m_{2}}\right|^{2} \cdot\left|c_{n_{1} n_{2}}\right|^{2}
\end{aligned}
$$

ここで,

$$
\begin{aligned}
& c_{m_{1} m_{2}}=<\psi_{m_{2}}(x) \mid \phi_{m_{1}}(x)> \\
& c_{n_{1} n_{2}}=<\psi_{n_{2}}(x) \mid \phi_{n_{1}}(x)>
\end{aligned}
$$

つまり，考えている系の固有モードとして， 式(28)のようにx座標と $\mathrm{y}$ 座標が変数分離されて いる系を仮定する限り，入射系の $\left(m_{1}, n_{1}\right)$ モ一 ドから受光系の $\left(m_{2}, n_{2}\right)$ モードへの結合効率 $\left|C_{m_{1} n_{1} m_{2} n_{2}}\right|^{2}$ は, 結合効率の $x$ 方向成分 $\left|c_{m_{1} m_{2}}\right|^{2}$ と $y$ 方向成分 $\left|c_{n_{1} n_{2}}\right|^{2}$ を別々に求め, それらの積 をとることにより求められる。なお, 以下にお いては, 単一モード系の議論に戻るため, モー ド番号をすべて零とする。

\subsection{0 次のガウシアンビームの結合}

(a) 軸ずれ·角度ずれのない場合

ここでは, 軸ずれや角度ずれがなくスポット サイズのみが異なった0次のガウシアンビーム の結合について考える。スポットサイズが各々 $w_{2}$ と $w_{2}$ である入射系の波動関数 $\psi_{1}(x)$ と受光系 の波動関数 $\psi_{2}(x)$ は互いに結合する面では, 波 面の曲率半径が無限大であるため, 次の式で表 される。

$$
\psi_{i}(x)=\left(\sqrt{\frac{2}{\pi}} \frac{1}{w_{i}}\right)^{\frac{1}{2}} \exp \left(-\frac{x^{2}}{w_{i}^{2}}\right)(i=1,2)
$$

この場合の結合効率 $\eta$ を式(32)に基づき計算す ると,

$$
\eta=\left|c_{00}\right|^{4}=\frac{4}{\left(\frac{w_{1}}{w_{2}}+\frac{w_{2}}{w_{1}}\right)^{2}}
$$


のように求まる。従って, ビームウェストの位 置が一致した場合の結合効率はスポットサイズ の絶対値ではなく, その比によって決定され, $w_{1}=w_{2}$ の時, すなわち, 入射系と受光系のス ポットサイズが一致した場合においてのみ， $=1$ ，つまり $100 \%$ 結合が得られる。ちなみに, スポットサイズが $1 \mu \mathrm{m}$ と $5 \mu \mathrm{m}$ の半導体レー ザーと単一モード光ファイバーを直接結合させ ると, その結合効率は $-8.3 \mathrm{~dB}$ 程度と低く, 結 合効率改善のためには像変換によるスポットサ イズ整合が重要となることがわかる。

ここで, 半導体レーザーと単一モード光ファ イバーの結合で見られるような入射ガウシアン ビームのスポットサイズが $x$ 方向に $w_{1 x}, y$ 方向 に $w_{1 y}$ と非対称で, かつ受光系のスポットサイ ズ $w_{2}$ が軸対称な場合における最適像倍率を考 える。

この場合の結合効率 $\eta$ は

$$
\eta=\frac{4}{\left(\frac{m w_{1 x}}{w_{2}}+\frac{w_{2}}{m w_{1 x}}\right) \cdot\left(\frac{m w_{1 y}}{w_{2}}+\frac{w_{2}}{m w_{1 y}}\right)}
$$

で与えられる。これが最大となるための最適像 倍率 $m_{\mathrm{opt}}$ は $\partial \eta / \partial m=0$ より

$$
m_{\mathrm{opt}}=\frac{w_{2}}{\sqrt{w_{1 x} w_{1 y}}}
$$

となる。さらにこの $m_{\mathrm{opt}}$ を式(37)に代入する と, 最大結合効率 $\eta_{\max }$ が

$$
\eta_{\max }=\frac{4}{\left(\frac{w_{1}}{w_{2}}+\frac{w_{2}}{w_{1}}\right)^{2}}
$$

として求まる。式(38)と式(39)から次のことが わかる。すなわち, 最大結合を得るには入射ガ ウシアンビームの非対称スポットをあたかも $x$ 方向と $y$ 方向の積の平方根で与えられる対称 ビームと考えてレンズの像倍率を決定すれば良 いが, 最大結合効率の值そのものには, 入射ビ 一ムの非対称性が式(39)の形で残る。

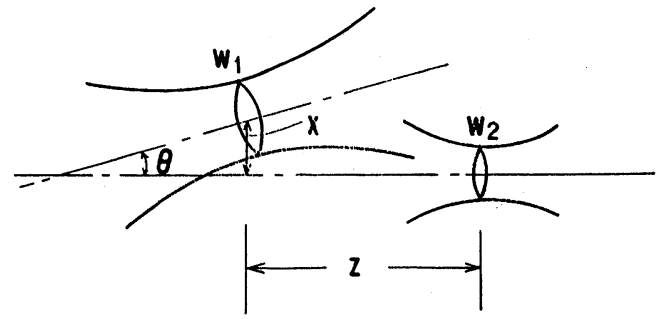

Fig. 7 Coupling between two Gaussian beams.

（c）軸ずれ角度ずれのある場合

ここでは, Fig.7のようにスポットサイズが $w_{1}$ の入射ガウシアンビームがスポットサイズ $w_{2}$ の受光系と光軸方向に $z$, 光軸垂直方向に $x$, 角度 $\theta$ だけずれて結合する場合を考える。この 時の結合効率 $\eta$ は

$$
\begin{array}{r}
\eta=\kappa \exp \left[-\kappa\left\{\frac{x_{0}^{2}}{2}\left(\frac{1}{w_{1}^{2}}+\frac{1}{w_{2}^{2}}\right)\right.\right. \\
\left.\left.+\frac{\pi^{2} \theta^{2}}{2 \lambda^{2}}\left(w_{1}^{2}(z)+w_{2}^{2}\right)-x_{0} \theta \frac{z}{w_{1}^{2}}\right\}\right]
\end{array}
$$

で与えられる。ここで, $\kappa$ と $w_{1}(z)$ は次式となる。 $\kappa=\kappa_{x} \kappa_{y}=\frac{4}{\left(\frac{w_{1}}{w_{2}}+\frac{w_{2}}{w_{1}}\right)^{2}+\left(\frac{\lambda z}{\pi w_{1} w_{2}}\right)^{2}}$

$w_{1}(z)=w_{1} \sqrt{1+\left(\frac{\lambda z}{\pi w_{1}^{2}}\right)^{2}}$

なお， $\boldsymbol{\kappa}$ は光軸方向の軸ずれのみがある場合 $(x$ $=\theta=0)$ の結合効率に対応し, $w_{1}(z)$ は受光系 端面における入射ガウシアンビームのスポット サイズを表す。

\section{5. 各種レンズ系}

ここでは，まず一般論として1枚レンズ系と2 枚レンズ系の像変換の公式を導く。次にこれら の公式に基づき,Fig. 8(a)に示す先球GRIN ロッドレンズや非球面レンズを用いる大レンズ 系, Fig. 8(b)の先球ファイバーに代表される微 小レンズ系, Fig. 8(c)に示すような2枚のレン ズを共焦点に配置する共焦点複合レンズ系な 


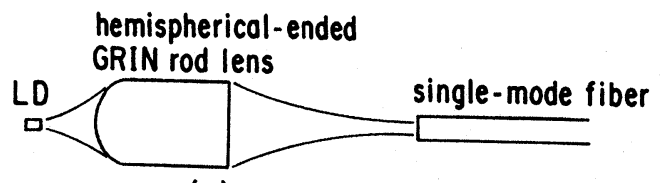

(a)

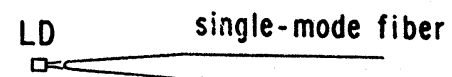

(b)

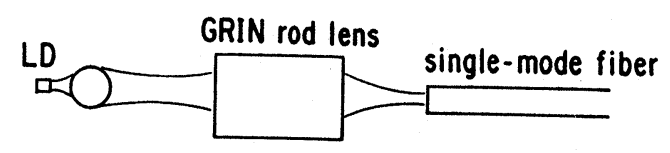

(c)

Fig. 8 (a) A large lens system, (b) A microlens system, (c) A confocal two-lens system.

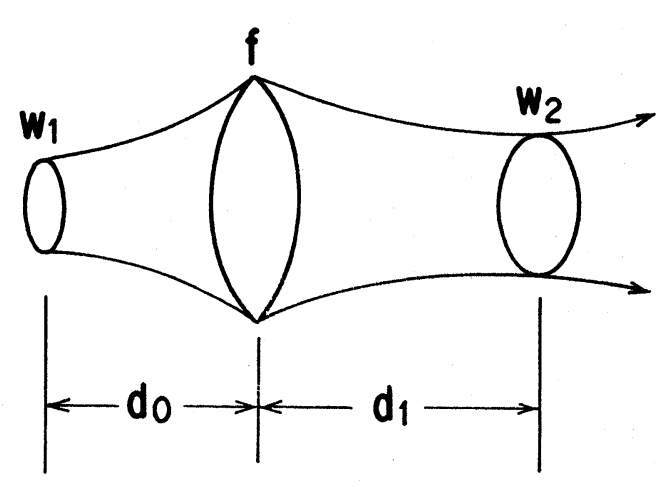

Fig. 9 Beam transformation using a one-lens system.

ど, 半導体レーザーと単一モード光ファイバー の結合において実際によく使用されるレンズ系 の結合特性について議論する。

(a) 1枚レンズ系

Fig. 9に1枚レンズを用いた像変換の概念図を 示す。入射ガウシアンビームのスポットサイズ を $w_{1}$, そのビームウェストからレンズの入射 側主面までの距離を $d_{0}$ とし, 像変換後のガウシ アンビームのスポットサイズ $w_{2}$ (すなわち像倍 率 $\left.m=w_{2} / w_{1}\right)$, およびレンズの出射側主面と ビームウェストまでの距離 $d_{1}$ を求める。系は厚 み $d_{0}$ の誘電体媒質, 焦点距離 $f$ の薄肉レンズ,
厚み $d_{1}$ の誘電体媒質から構成されているので, 系全体の光線行列 $(M)$ は次式で与えられる。

$$
(M)=\left(\begin{array}{ll}
1 & d_{1} \\
0 & 1
\end{array}\right)\left(\begin{array}{cc}
1 & 0 \\
-\frac{1}{f} & 1
\end{array}\right)\left(\begin{array}{ll}
1 & d_{0} \\
0 & 1
\end{array}\right)
$$

従って, 式(24), 式(25)に示した公式から変 換後のビームウェストの位置 $d_{1}$ とスポットサイ ズ $w_{2}$ が求まる。

$$
\begin{gathered}
d_{1}=\frac{\left(\frac{\pi w_{1}^{2}}{\lambda}\right)^{2} \frac{1}{f}-d_{0}\left(1-\frac{d_{0}}{f}\right)}{\left(\frac{\pi w_{1}^{2}}{\lambda}\right)^{2}\left(\frac{1}{f}\right)^{2}+\left(1-\frac{d_{0}}{f}\right)^{2}} \\
\left(\frac{w_{2}}{w_{1}}\right)^{2}=\frac{1}{\left(\frac{\pi w_{1}^{2}}{\lambda}\right)^{2}\left(\frac{1}{f}\right)^{2}+\left(1-\frac{d_{0}}{f}\right)^{2}}
\end{gathered}
$$

と求まる。これらの公式を用いることにより， 1枚レンズ系でありさえすれば, 焦点距離の長 い大レンズ系から先球ファイバーのような焦点 距離の短い微小レンズ系まで設計することがで きる。

次に，1枚レンズ系の公式を用いて，大レン ズ系と微小レンズ系における像変換後のスポッ トの位置とその大きさについて考察する。

焦点距離 $f$ が数 $100 \mu \mathrm{m}$ からミリオーダとス ポットサイズ $w_{1}$ に比較して充分長い大レンズ 系の場合, つまり

$$
\left(\frac{\pi w_{1}^{2}}{\lambda}\right)^{2}\left(\frac{1}{f}\right)^{2}<\left(1-\frac{d_{0}}{f}\right)^{2}
$$

の場合には, 式(44), 式(45)から幾何光学の式

$$
\begin{aligned}
& \frac{1}{d_{0}}+\frac{1}{d_{1}}=\frac{1}{f} \\
& m=\frac{1}{\frac{d_{0}}{d_{1}}}=\frac{d_{1}}{d_{0}}
\end{aligned}
$$

を導くことができる。 
一方, 焦点距離 $f$ $10 \mu \mathrm{m}$ 程度と短い微小レン ズ系の場合には, 式(44)と式(45)の分子.分母の 第2項は第一項と比較して無視できる。すると ただちに

$$
d_{1}=f
$$

および

$$
w_{2}=\frac{\lambda f}{\pi w_{1}}
$$

あるいは

$$
f=\frac{\pi w_{1} w_{2}}{\lambda}
$$

また，式(50)を式(45)に代入すると

$$
d_{0}=\dot{f}
$$

となる。つまり, 微小レンズ系では, 微小レン ズの入射側主面からfの距離にビームウェスト を配置するとレンズの出射側主面から $f$ の位置 に式(50)で与えられるビームウェストが形成さ れることがわかる。

(b) 2枚レンズ系

Fig. 10は2枚レンズ系による像変換の概念図 である。レンズ 1,2 の焦点距離を $f_{1}, f_{2}$, 入射 ガウシアンビームのスポットサイズを $w_{1}$ ，そ のビームウェストからレンズ1の主面までの距 離を $d_{0}$, レンズの間隔を $d_{1}$ とし，レンズ 2 出射 後のガウシアンビームのスポットサイズ $w_{2}$, レンズ2の出射側主面からビームウェストまで の距離 $d_{2}$ を求める。この系は厚み $d_{0}, d_{1}, d_{2}$ の 誘電体, レンズ 1 , レンズ $2 て ゙$ 構成されているた め, 光線行列 $(M)$ は

$$
\begin{aligned}
(M)= & \left(\begin{array}{ll}
1 & d_{2} \\
0 & 1
\end{array}\right)\left(\begin{array}{cc}
1 & 0 \\
-\frac{1}{f_{2}} & 1
\end{array}\right)\left(\begin{array}{ll}
1 & d_{1} \\
0 & 1
\end{array}\right) \\
& \times\left(\begin{array}{cc}
1 & 0 \\
-\frac{1}{f_{1}} & 1
\end{array}\right)\left(\begin{array}{ll}
1 & d_{0} \\
0 & 1
\end{array}\right)
\end{aligned}
$$

で与えられる。 $w_{2}$ と $d_{2}$ は式(24), 式(25)からた

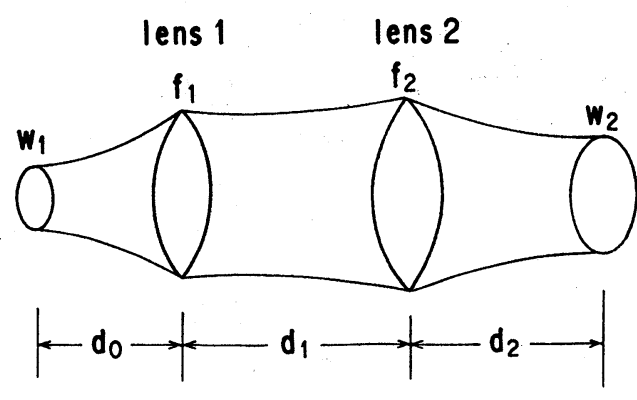

Fig. 10 Beam transformation using a two-lens system.

だちに求まるが， $d_{0}=f_{1}, d_{1}=f_{1}+f_{2}$ と配置する と

$$
\begin{aligned}
& d_{2}=f_{2} \\
& m=\frac{w_{2}}{w_{1}}=\frac{f_{2}}{f_{1}}
\end{aligned}
$$

すなわち, 共焦点配置となる。この共焦点系で は, 像倍率 $\mathrm{m}$ は2つのレンズの焦点距離の比 $f_{2} / f_{1}$ によってのみ決定されるという興味深い特 徵を持つ。

\section{6. おわりに}

半導体レーザーを主眼としてレーザー光と単 一モード光ファイバーとの結合系設計の手法に ついて，ガウシアンビーム近似に基づいて概説 した。実際に光デバイスを設計するには，紙面 の関係で割愛したが,この他にレンズやファイ バーなどの光学系構成要素が軸ずれした場合に 結合効率へ与える影響を知っておく必要があ る。また, レーザー光と多モード光ファイバー との結合については, 従来用いられてきた光線 追跡法では結合効率, 軸ずれ特性とも実験とか け離れたものとなるが, 著者らが提案した高次 モードの損失項をとり入れた手法により，これ を大幅に改善できる。これらの点に興味がある 方は文献(1)を参照していただきたい。

\section{参 考 文 献}

1) 河野健治: 光デバイスのための光結合系の基 礎と応用, 現代工学社 (1990). 